\title{
'Weeping tears of blood': Exploring Italian soldiers' emotions in the First World War
}

\begin{abstract}
Vanda Wilcox*
Department of History and the Humanities, John Cabot University, Rome, Italy

(Received 27 January 2011; final version accepted 10 January 2012)

Emotion plays a vital role in any rounded history of warfare, both as an element in morale and as a component in understanding the soldier's experience. Theories on the functioning of emotions vary, but an exploration of Italian soldiers' emotions during the First World War highlights both cognitive and cultural elements in the ways emotions were experienced and expressed. Although Italian stereotypes of passivity and resignation dominated contemporary discourse concerning the feelings and reactions of peasant conscripts, letters reveal that Italian soldiers vividly expressed a wide range of intense emotions. Focusing on fear, horror and grief as recurrent themes, this article finds that these emotions were processed and expressed in ways which show similarities to the combatants of other nations but which also display distinctly Italian features. The language and imagery commonly deployed offer insights into the ways in which Italian socio-cultural norms shaped expressions of personal war experience. In letters that drew on both religious imagery and the traditional peasant concerns of land, terrain and basic survival, soldiers expressed their fears of death, isolation, suffering and killing in surprisingly vigorous terms.
\end{abstract}

Keywords: First World War; combat; emotions; fear; morale; letter-writing

\section{War and emotion}

Few subjects evoke such strong emotional reactions as war, incorporating as it does such emotion-laden phenomena as separation, patriotism, danger, hatred and death. Emotions are a central element in the experience, representation and memory of armed conflict, and the emotions of war can range very widely through fear, horror, anger, grief and shame as well as love, friendship, loyalty, even excitement. While scholars working on the First World War have long been interested in questions relating to morale and to soldiers' identity and experience, more recent research has focused explicitly on emotions themselves (Das 2005; Roper 2009), exploring both their psychic and bodily dimensions. This paper will build on insights applied to other armies of the First World War to consider Italian soldiers' emotions.

Methodological doubts, difficulties of definition and the problems of subjectivity have sometimes made historians reluctant to engage directly with emotions (Rosenwein 2002,

\footnotetext{
*Email: vwilcox@johncabot.edu 
821-22; Bourke 2005, 6). In his article 'What is an emotion?' Klaus R. Scherer defines emotion as including not only 'feelings' (the subjective interior reaction component) but also the process of situational appraisal, judging events or objects; physiological responses such as heightened heart-rate, sweating or tears; and some kind of communication of both reaction and intent such as facial or verbal expression (including in writing) (2005, 697-99). Emotions are linked to stimulus events whether internal (memories) or external (witnessing or participating in an activity), and are appraisal driven in that they are appraised by the individual as being of importance in some way (Scherer 2005, 700-01). For cognitive psychologists, emotions are the product of perceptions and judgements made based on these perceptions, as to whether something is harmful or beneficial. Though emotions are often perceived as irrational, or posited in contrast to reasoned judgements, they are in fact reactions arising from cognitive analysis. Soldiers' emotions in wartime are thus the direct product of their appraisal of their experiences in battle or at the front. Physical and mental reactions, the concrete manifestations of emotion, follow on from this process of perception and appraisal. 'Emotionologists', by contrast, take a social constructivist approach, arguing that society's standards and expectations for emotional expression have a significant impact on individuals' behaviours and interior lives. Individuals may be subject to different social rules or discourses in different contexts or 'emotional communities' (Rosenwein 2002, 836-39; Bourke 2005, 73-76).

I argue that both the cognitive and constructivist models can illuminate our understanding of Italians' emotions during the First World War. The emotional responses of men in combat have a number of universal features, since they are directly linked to the cognitive appraisal of (combat) experience. We can identify transnational similarities within individual conflicts. Though the mountainous and rocky terrain in which most Italians fought was very different from that of the Western Front, the Italian theatre of war was similarly immobile on both the Alpine and Isonzo fronts for almost the entire war. Artillery and machine-gun fire accounted for the majority of casualties while hand-to-hand combat was relatively rare. The nature of warfare and conditions of combat, governed by the technological and tactical circumstances of the day, determine combat experience and hence influenced emotional reactions. But if the prevailing discourses of different societies and cultures help to shape emotional forms of expression, we may be able to identify specifically Italian features to the forms in which men expressed and communicated their emotions. As Bourke observes, 'the bruising encounter between individual subjectivity and social norms' defines the contours of emotion $(2005,9)$.

This article focuses primarily on fear, since it is central to the nature and outcome of war: it can limit men's ability to fight effectively whether offensively or defensively, and thus determines the army's ability to defeat the enemy in battle. All armies in 19141915 placed considerable emphasis on the idea of offensive spirit or 'moral shock' as a key element of tactical success; an army needed to instil fear and panic in the enemy while avoiding it among its own men.' By contrast, individuals needed to manage their fear in order to protect their own physical and mental health, through emotional and psychological coping strategies to deal with terror, horror, and panic. The letters analysed below represent one means through which soldiers processed difficult emotions. 


\section{Constructing and reconstructing emotions}

Since 'historically, subjective feelings are invisible' (Bourke 2005, 6) we must rely on documentary evidence of individuals' feelings and the ways in which these have been manifested through bodily actions or reactions such as fainting, flight or tears. While soldiers' letters can provide the most immediate access to emotions in war there are several problems with this source, not least the practice of censorship. In Italy this was carried out both by men's immediate frontline superiors at the point of despatch and by civilian officials throughout the country prior to delivery. Though it has been estimated that, due to the volume of mail, the shortage of funding and personnel, and the pressures of time, only around $2 \%$ of letters were scrutinised thoroughly (Forcella and Monticone 1968, xxiv), any expression of defeatism, alarmism or negativity could in theory lead to prosecution. Consequently men found it risky (as well as potentially embarrassing) to express emotions openly under this disciplinary regime, a problem that was frequently if obliquely explored in letters (Bellosi and Savini 2002, 17-18). A less tangible problem is self-censorship, whether through consideration for the intended audience - civilians, family members - or a sense of cultural and social pressures which impeded frank expression of emotions.

Diaries written for personal use can help overcome this issue, as can memoirs and oral testimonies, though these raise their own questions of memory and reliability. Some memoirs emerged immediately after the war but many more were published under fascism and thus faced new problems with censorship. It is also notable that diaries and memoirs were most commonly produced by middle-class junior or mid-ranking officers, and while they have been extensively studied (Isnenghi 1967, 2002) they are perhaps more useful for considering the mythology and cultural presentation of the war, or the perceptions of the more educated and literate classes, than the experience of ordinary infantryman. The preponderance of middle-class memoirs means that it has generally been easier to explore the experiences of these groups rather than those of peasant soldiers, hence this article deliberately seeks to focus explicitly on less educated men whose writings have sometimes been neglected. A final consideration on sources is the psychological difficulty, perhaps even impossibility, of accurately turning emotion into a narrative. There is evidence to suggest that actually the process of turning an emotional experience into some form of narrative, whether simply to be recounted orally or to be preserved in a letter or diary, is the fundamental means by which soldiers process battle trauma and its emotional pressures. In essence, the text is created in the interests of the writer, not the reader. ${ }^{2}$ The urge to write and narrate was powerful: though some men 'trembled to write of the terrible carnage' (Procacci 2000, 425) ${ }^{3}$ and many struggled greatly with the mechanics of writing, ordinary soldiers persisted in producing not only letters but also (in lesser quantities) diaries and memoirs, suggesting that it was almost a psychological imperative, fulfilling a vital therapeutic function (Gibelli 1987).

This observation raises one of the problems specific to the Italian case in 1915-1918: a significant impediment to the written expression of soldiers' emotions was the low rate of literacy among the troops. The national literacy rate in 1915 was around $65 \%$, with figures ranging from around $90 \%$ in some northern cities to under $35 \%$ in rural areas and parts of the South (Gibelli 1998b, 93). ${ }^{4}$ This issue is linked closely to the social profile of the armed forces: 4,250,000 men served under arms in the war zone, an almost entirely conscript force (only 8171 men served as volunteers, mostly middle-class irredentists) (Ministero della 
Guerra, Ufficio Statistico 1927). The infantry was disproportionately drawn from the peasantry - the social group with the lowest literacy levels; the urban working classes were more likely either to be in reserved occupations (they constituted $18 \%$ of the national population in 1911 but only $11.5 \%$ of the armed forces in 1915-1918) and even within the army many were assigned other roles which required literacy or a degree of specialisation, such as the artillery and engineers (Gibelli 1998b, 86-89). To focus on ordinary private infantryman means to focus primarily on the peasantry and rural working class, who suffered the heaviest burden in terms of casualties - and were most likely to struggle with literacy. Many learned to read and write for the first time in the trenches, while those who had acquired some level of literacy before the war found themselves putting their skills into practice for the first time in their adult lives. This precarious grasp on literacy is evinced in the syntax, lexical choice, dialect elements and orthography of the surviving letters written by peasant and rural working-class soldiers, which are often extremely hard to read. ${ }^{5}$ Studies of literacy and cognition suggest that the process of learning to read and write entails a psychological and cognitive transformation: 'Literacy imparts a degree of abstraction of thought which is absent from oral discourse', and can significantly increase analysis and criticism of both events and systems of representation (Olson 1994, 7). It seems clear that literacy offers 'potentialities', without which 'some kinds of cognitive development are impossible' (Stephens 2000, 17). In other words the act of transforming lived experience into a written text is highly significant, a process that involves both abstraction and cultural mediation. It is here in this transformation that we can best identify the distinctive social and cultural elements of Italian soldiers' emotional experience. The language and terminology used by peasant soldiers is indicative of their mental landscapes as much as their wartime experiences.

Another impediment to the full expression of Italian peasants' emotions was the prevailing elite assumption that the peasantry were not just ignorant but resigned and apathetic. A discourse of peasant resignation was offered in implicit contrast to the unreliable and demanding industrial working class, who in this analysis were at best selfish and at worst actively unpatriotic (Isnenghi 2002, 325-29). Agostino Gemelli, a pioneer of Italian military psychology, argued that those without hope, ambition or education found it easiest to adapt to the war, greeting it with resigned acceptance (1917, Chapter 10). This view of passivity extended beyond the manly acceptance of hardship into the vision of a peasantry too rustic, simple and apathetic even to experience suffering in the same way as more sophisticated men. Actively celebrated and idealised as both a political and a military virtue, this model of passive stoicism left little space for either intellectual or emotional agency on the part of peasant conscripts. These assumptions may have made it harder for men to express their emotions, given that resigned passivity was clearly indicated as the safest, most acceptable mode of behaviour.

Perhaps unsurprisingly, statements of fatalism and passivity are found in many peasant letters or reminiscences, with many comparing themselves to sheep (Revelli 1977, 232; Bellosi and Savini 2002, 311). Equally common are signs of the struggle to achieve such resignation: 'What can we do, nothing, we must resign ourselves and hope for peace', wrote Dino Del Greco, a blacksmith from near Cesena to his mother. He continued: 'but I can't resign myself' (Bellosi and Savini 2002, 257). Fatalism can be found in the portrayal of the war as a natural disaster, comparable to crop failure (Bellosi and Savini 2002, 274-75) or an earthquake, echoing the catastrophe of Messina in 1908 (Gibelli 1998a, 20-21). But fatalistic acceptance of the war did not prevent peasant soldiers from 
displaying a variety of forms of resistance, both hidden and overt, or experiencing a full range of emotions. Indeed modern scholarship has challenged and modified the very notion of peasant passivity in general (Scott 1985) and it is by no means clear that Italian peasants were, in fact, passive. Rather, resignation - both real, if limited, and as a prevailing cultural discourse - shaped the ways in which soldiers represented and narrated their emotions not only to others but also to themselves.

Contemporary notions of masculinity based on courage, determination, virility, were similarly important in legitimising certain forms of emotional expression, while undermining those that seemed weak or effeminate. As in other societies, manliness and patriotism required emotional control, suppressing the outward expression of fear or distress (Loez 2003, 216-19; Meyer 2003). But the British working-class model of stoical endurance included an assumption of confidence in the outcome of the war, rather than indifference or doubt (Winter and Prost 2005, 94-95). By contrast, there was relatively little focus on aggression or fighting spirit as a complementary element of working-class Italian masculinity: rather peasant endurance and the capacity for silent suffering were themselves cast as manly qualities, while the war was a chance to reassert Italian virility against the decadent effects of modernity (Bellassai 2005, 316-18). Despite these discourses of passivity (so often seen as a female quality) and masculine repression, peasant soldiers could and did express their fears in a variety of ways, using familiar mental markers of civilian life to communicate their feelings through evocative metaphors. Men 'bled like goat[s]' or else advanced enthusiastically 'like goats going after salt' (Revelli 1977, 101, 255); one compared himself to a huntsman pursuing the Austrians for sport, while another used familiar images to describe unfamiliar scenery: 'our artillery has been aiming their fire at the Podgora [mountain] for two months and they have plucked it like a chicken' (Bellosi and Savini 2002, 377, 404).

Alongside verbal expressions of emotion we also find bodily manifestations of feeling mentioned in the written record, including reports of trembling legs and hands, and above all of tears. During the 10th battle of the Isonzo in May 1917, official historian Angelo Gatti reported that 'in these recent engagements ... soldiers advanced crying. They did not rebel: when ordered out of the trenches they obeyed; but they went crying' $(1964,61)$. British liaison officers on Monte Grappa reported in November 1917 that:

Most of the men in the trenches were very young.... Many of them were weeping and some had ice on their faces: the conducting officer said that three or four of them were frozen to death nightly. (Edmonds 1949, 116)

Soldiers themselves also described their own 'long fits of crying' (Beltrame Menini 2001, 146). 'Often we look one another in the face seeing each other shattered with hunger and sleep - tears fill our eyes, crying like babies', wrote an infantryman to his fiancée in April 1916 (Procacci 2000, 425).

\section{Italian soldiers' fears in the First World War}

Given the above caveats regarding sources and contemporary social norms, how do we find Italian soldiers expressing their fears and other associated emotions? In contemporary wartime discourse, profound fear - or at least its display - was read as a sign of mental and moral infirmity and 'pathologised' as a potential symptom of psychological instability (Gibelli 1998a, 64-70). This made it harder for men to express fear, as did the model of 
'virtuous passivity', but nonetheless many soldiers were quite explicit about their emotions, including in letters to their families. The idea that all soldiers constantly tried to shield civilians from the brutalities of war is a simplification, though in Italy as elsewhere soldiers were more frank with friends and siblings than with parents or wives (Gibelli 1998a, 59), while generally male correspondents at home received more detailed information than females (Roper 2009, 67).

Contrary to what we might expect, fear was not necessarily at its most intense during combat itself but was exacerbated by immobility: long hours in the trenches, especially under bombardment, left men with plenty of time to reflect and think about the future, whereas during assaults or the mental concentration of some activity there was no time to focus on danger or feel one's terror (Frescura 1981, 259; Bellosi and Savini 2002, 218). This supports the idea of emotions as constructs, based on a cognitive process which goes beyond the instinctive.

\section{Death}

The fear of death is perhaps the most obvious of all combat-related anxieties. Frequently, fear for oneself was expressed tangentially through other emotions such as empathy for others in the forms of grief or mutual concern, perhaps more socially acceptable than admitting to fear for one's own safety. A soldier named Sebastiano from the Veneto wrote to his brother-in-law in Argentina:

....as we fight we see men falling to the ground like flies look to see young men like this are things which would make even the stones cry I Often start to cry myself as I see things like this and yet from one day to the next it will be my turn as well but let's hope with the help of god I'll have at least the luck to go home once more. (Procacci 2000, 427) ${ }^{6}$

Here the writer invokes both divine assistance and chance - going home would require both God's help and a dose of luck. It is notable too that he hopes not to survive but, pessimistically, for the more limited aspiration of seeing home (and family) at least one more time. He justifies his own (unmanly?) tears by emphasising the intensity of the horror he witnesses: if 'even the stones' would cry, then there can be no shame that he too is frequently reduced to tears.

Fear for oneself went hand in hand with grief for others:

Now listen to the civilisation of our wonderful Italy, I tell you we are treated like dogs and in our service we are in all respects theirs [the authorities']. When I think about it, it breaks my heart, I find myself among grief and tears, I tell you that among the dead, who are our brothers, we walk as though we were walking on the stones in a river, this is the civilisation of our Italy. (Procacci 2000, 404)

The comparison between the dead, 'our brothers', and the stones in a river, suggests the dehumanising nature of mass death and the innate trauma arising from the impossibility of treating the dead with appropriate ritual or respect. Again the author sees no shame in admitting to his tears given the intensity of his emotion, surpassing his 'threshold of suffering' (Loez 2003, 213).

Both these letters use the imagery of stones: rocks and the hard unforgiving landscape feature very commonly in peasant soldiers' narratives: 'The war of ' 18 left only wretchedness, they conquered some useless mountains and a pile of bloody rocks' 
(Revelli 1977, 73). Here rocks indicate the worthlessness of the land that Italy acquired, a concern which for peasants was especially pertinent: if the hard-won land was infertile and barren, what use was it - and what use were their sacrifices? This kind of practical assessment of territorial claims ignored lofty ideals about nationality. Peasant Giovanni Allinio (born 1895) recalled the battles of 1916:

I went to Monfalcone, then Monte Sei Busi, a terrible affair, so many dead ... the earth of the trench was red like roof tiles, all clayey, our faces were always dirty. I was sent over the top twice, what a terrifying experience.... (Revelli 1977, 101)

Once again the land was seen as worthless from a farmer's perspective, though this emphasis on soil and rocks is not dissimilar to British troops' complaints of their 'troglodyte' earth-bound existence (Leed 1979, 139). Men slept 'underground like toads' or 'inside the ground like animals' (Bellosi and Savini 2002, 245, 398) and compared themselves to foxes and moles living in lairs: men felt reduced to the level of beasts, dehumanised not by the mechanical, industrialised features of the war so much as its primitive aspects. Since life in the trenches was literally delimited by walls of earth, mud or stones, these came to define both physical and mental horizons. Land was also a constant concern for the peasantry, such that it was seen as the dominant motive and explanation for the conflict: 'War is just stealing land from one another and killing people' (Revelli 1977, 212).

The prevalence of earth and soil naturally led to thoughts of burial: one soldier wrote from Oslavia to a friend back home in Como in 1916: 'my health is still OK even here buried beneath the earth in this trench' (Procacci 2000, 407). He was not alone in feeling 'entombed': burial alive was a recognised psychological obsession for soldiers in modern war, according to Italian studies of the Russo-Japanese war carried out before 1915 (Gibelli 1998a, 35). Some felt as if death was not just on its way but had already taken them, as another infantryman reported: 'In the trenches during a bombardment you think of nothing - I can't even think about my wife and children ... it's as though I was already dead' (Gemelli 1917, 57).

Returning to the link between grief and fear, junior officer Attilio Frescura wrote in his diary:

A body, sprawled along the roadside, can wring your heart with sadness, but even more with fear, because we see ourselves lying there just like that, livid, vacant, substance without the breath of spirit. If the sight of the dead continues, all along the roads, across all the fields, lying unknown in all the ditches, then the sadness disappears, we grow inured to it. But the fear lives on. $(1981,269)$

Grief for fallen comrades did not necessarily lead to disillusionment and disaffection with the war as a whole. In the British and German armies a kind of sacrificial ideology sometimes operated whereby survivors sought to honour the fallen through attaining the objective for which they died - national victory - thus 'channelling men's grief and guilt in ways which raised armies' resilience' (Watson and Porter 2010, 162). In Italy too this process could sometimes be identified: one junior officer observed in the autumn of 1917 that his men were now motivated by 'all the hate accumulated through the years of this conflict' (Garrone and Garrone 1974, 413). Yet anger born out of grief was not always directed at the enemy; for Italian soldiers it was often their own government that was the target, blamed for needlessly provoking or prolonging the conflict. 
A legitimate language for the expression of intense emotion - including this anger was provided by religion. In June 1916 an anonymous letter to a prominent supporter of the war in Pavia explained:

We came here to defend the Patria but now we have been fighting for 13 months without having gained anything, on the contrary so many of our Poor brothers are dead and so many poor Fathers and Mothers weeping tears of blood just like their beloved sons... we think that we can no longer endure this evil life, and we say this in great faith as we pray every day to God and the Saints and to those who must take the blame for making this Cursed war. (Procacci 2000, 430)

Explicit appeals to religion are frequent in peasant letters, but not in an especially devotional way; more often religious faith and practice acted as a source of metaphor and imagery, such as the common description of Gorizia as a Calvary. Antonio Tognella, from the province of Verona, wrote to his fiancée in August 1915 from near Asiago: 'You should know that this is a vale of tears where we have nothing but sorrows and we suffer every kind of tribulation' (Beltrame Menini 2001, 81). The idea of 'Fathers and Mothers weeping tears of blood' evokes the numerous examples of images or statues of the Madonna weeping blood in the Italian devotional tradition; wartime parental bereavement could effectively be linked to the image of the Madre Dolorosa. Indeed the Madonna was frequently depicted weeping in response to soldiers' sufferings. ${ }^{7}$ Expressions of concern for the emotional hardships of close family members were common; like religion, the family was a sphere in which men could express feelings without compromising masculine control. Tognella expressed his fear of death through concern for his fiancee, describing the physical manifestations of his feelings as he once more faced the prospect of combat after his experience in the Libyan War in 1911:

Thinking to myself it seems that my heart must leap out of my chest and my mind is shaken to the point of madness. Not for me, you understand but for you my adored Luigia.... How sad and unendurable is my destiny. (Beltrame Menini 2001, 68)

Another common fear was a lonely death far from home and friends, with none of the idealised consolations of heroism or comradeship. Volunteer irredentist Guido Favetti wrote in his diary in January 1916:

What breaks my heart is the simple, silent way these unhappy men die and disappear, ignored by everyone. The poor devils go without even a friend at their side, nothing: at best some rough [male] nurse and no other - and perhaps even he won't have been there in the last moments! Imagine dying like this, alone, abandoned by everyone... dying like an animal! $(2004,85)$

\section{Suffering, wounds and punishment}

Besides death, soldiers also had to confront the fact that even if they managed to return alive from the war they might well be seriously disabled or suffer long-term physical and psychological damage from wounds and illness. One man wrote to his girlfriend Serena about his fear of bodily mutilation and the 'nervous' symptoms his night terrors were causing:

At night I can't sleep because my whole body is shaking with nerves and the beat of my heart: no no no. There are all those dead, who will never go home again; or those who return without their legs, without their eyes, and will never see the sun again. Isn't it true? Tell me I'm right, I know I'm right to weep. (Spitzer 1976, 126) 
Fear of pain and suffering could override even the fear of death. Favetti explored the idea of assisted euthanasia:

Here is my greatest desire, to die instantaneously rather than suffering so terribly. I always say to my colleagues...that I'd be delighted to meet one who would have the guts, upon my formal request, to end my wretched life if necessary. ... Instead, when you are mortally wounded, you don't have the ability or even the tools at hand. This is what is terrible. $(2004,83)$

Italian soldiers were also justifiably afraid of their own army authorities: military discipline was notoriously harsh (Wilcox 2005), and Chief of General Staff Luigi Cadorna in describing his man-management policies wrote that 'without instilling fear in everyone, nothing is achieved' (Cadorna 1967, 197). In memoirs or oral recollections men reiterate that they advanced or attacked only through fear of execution (though this is unsurprisingly harder to identify in letters). Pasquale Roggero recounts a tragicomic episode in which his fear of returning to the front after home leave battled with his fear of the punishment which the disciplinary system would impose if he were caught as a deserter. Three times Roggero went to the station at Bra to catch a train back to the front; three times he panicked at the thought of the intense fighting which he knew was imminent, and fled home again. All in all he was away from the lines for 47 days before the fear of possible detection outweighed his fear of combat and he finally steeled his nerve to return to the front (Revelli 1977, 291-92).

\section{Killing}

Another source of fear and anxiety for front-line soldiers was the psychologically traumatic requirement to kill, which most acutely embodied the transformation in status and identity from civilian to military life. The issue of soldiers' attitudes to killing has been vigorously debated in the historiography. S.L.A. Marshall's research in the Pacific theatre during the Second World War famously claimed that fewer than $25 \%$ of men fired their weapons in combat (2000). Though his statistics and methods have been widely criticised since publication in 1947 , his general thesis that many infantrymen seek to avoid killing when in combat has gained a degree of consensus. David Grossman, in his study On killing, argues that a combination of instinctive psychological reactions and cultural conditioning act to make killing a traumatic event which can induce guilt, horror and fear $(1995,29-39)$.

This important aspect of soldiers' experience, too often neglected, can be identified in a number of Italian memoirs and letters. One man wrote to a 'comrade' in Foggia:

... in civilian life I always behaved myself with honour and now they want me to be an executioner ah no up to this moment I haven't once had the courage to fire at another man like me and I'll never have it those who believe that the Austrians are their enemies can come and kill them I don't want to kill them.... (Procacci 2000, 406)

The contrast between 'honour' and the requirement to kill suggests that for this man there was no honourable killing to be found on the battlefield. Such killing was perceived as 'execution', which was fundamentally dishonourable. Being ordered to kill was particularly difficult for conscripts, as opposed to volunteers or professional soldiers: the ethical and cultural patterning of civilian life could not easily be overridden by an externally imposed identity (Leed 1979, 9-10). 'I swear to you I will make myself 
immediately a prisoner', the writer continued, rejecting soldierly duty altogether. Also interesting is the linguistic breakdown in this section of the letter: the opening shows slightly better grammatical structure than this wholly unstructured section, which is almost a stream of consciousness as he confronts the trauma of being ordered to kill. ${ }^{8}$ Pasquale Roggero later recalled:

I never fired my weapon during the war. Why shoot? Sometimes they gave me an order to shoot when I was on patrol: I planted the end of my rifle on the ground and fired at the sky, then I listened to the bullet coming back down, I don't know him over there, why should I kill him? [lù cunus nen chielli, perché maselu?]. (Revelli 1977, 291)

Hatred of the enemy can serve as a vital factor in overcoming men's reluctance to kill (Grossman 1995, 76-82), yet among Italian peasant conscripts hatred or rage towards Austro-Hungarians, described as the 'so-called enemy' (Procacci 2000, 423), was relatively scarce. In fact in all societies it seems that front-line experience often tended to diminish hatred of the enemy, which was more common among non-combatants (Leed 1979, 106-07). Civilians and especially women seem to have produced the most virulent anti-Austrian emotional language, as one letter from 1916 suggests:

Some stupid young woman, who thinks herself educated, has written to me from Naples: 'at the end of the war, bring me bit of [Emperor] Franz Josef's right ear! If I, a woman, were able to be in your place, I would be so proud to suffer for the Patria!'

But if this stupid young woman had seen some heads flying, a bunch of men disappearing in the explosion of a howitzer [shell] leaving not even a bone behind to be found afterwards ... then she'd write differently! (Procacci 2000, 411)

Soldiers from non-border regions and in particular the South had little reason to hate the Austrians, as Trieste-born volunteer Luigi Ius explained in his diary:

Many of them [the Sicilians] however... had no awareness of the war. They knew we were going against the enemy, which was Austria - and which they, lucky things, had no knowledge of and which many of them heard named for the first time. (Ius and Ius 2003, 35)

Pietro Bruno from the Valle Stura near Cuneo reminisced about his feelings towards the enemy:

During the attacks we were ordered to keep firing until we got up close. Then we were supposed to move on to cold steel and cut their throats with bayonets. But before we ever got down to hand to hand fighting they would begin to run away and we would also begin to run away.... (Revelli 1977, 199)

If soldiers are afraid to enact violence, then how can they prove effective on the battlefield? Killing at a distance, by artillery or machine gun fire, was much easier, with an inverse correlation between distance and willingness to kill: the closer the combatants, the greater the resistance to inflicting fatal injuries (Grossman 1995, 97-137). The intensity of the emotion can be seen in the action it produced: Bruno's fear of hand-to-hand killing was so powerful it induced him and his unit to flee.

Though highlighting the effort put in by all armies to train their men to kill, and the difficulties involved in overcoming mankind's innate resistance to the act of killing, Joanna Bourke has emphasised 'the centrality of killing in modern battle' and suggested that willingness or even enthusiasm for the act was widespread in both world wars (1999). This kind of enthusiasm is best exemplified in the Italian case by the relatively few men who were selected to join the Arditi, the elite assault unit created in July 1917, which 
perhaps surprisingly incorporated a substantial proportion of peasants (Rochat 1990, 41-46). But it is hard to identify these sentiments more widely in the sources; the rare references to killing the enemy nearly always associate it with alcohol, as a means to numb men's emotions.

\section{Conclusion}

The fears presented here - of death and killing, of wounds and mutilation, of isolation, loss and loneliness - were all essentially realistic. Men's fears were reasonable cognitive responses to the 'stimulus events' they observed and experienced directly as part of their military service. It is perhaps surprising how explicit some soldiers were about their emotions in writing, but the desire to communicate effectively in writing with family and loved ones was clearly powerful. Although the emotions associated with the experience of combat are personal and subjective we can see that common experiences go far beyond the limitations of nationality, theatre of war or indeed conflict: soldiers' experience of industrialised warfare in the Second World War is not dissimilar in many respects. However, we can find uniquely Italian discourses concerning emotions and emotional behaviour in the ways in which First World War soldiers processed, recorded and remembered their experiences. Exclusive emphasis on the forms of discourse and the linguistic codes through which emotions were communicated risks eroding the intensity and personal reality of emotion: 'the pain of loss threatens to be rationalized away' (Roper 2009, 26-27). Yet the distinctive forms of expression used by Italian peasant soldiers were part and parcel of how these men themselves experienced their emotions.

It has often been argued that the experience of combat in the First World War was profoundly transformative and marked a decisive rupture with the past (Fussell 1975; Leed 1979; Winter and Prost 2005, 182-83). In the Italian case this argument forms part of a teleological narrative regarding the relationship between the war and the rise of Fascism, often citing the futurist and avant-garde movements as evidence (Gibelli 2002; Gentile 2008). Antonio Gibelli goes so far as to claim that the 'mental landscape... of illiterate peasants was not very different from that of the middle-classes and intellectuals. There is a link between the language of the artistic avant-garde... and the mental representations of ordinary men' (Gibelli 1998a, xii). In general though, the argument that the war was the disruptive herald of cultural modernity in all European societies is rooted strongly in high culture, especially in the literary production of social elites. In fact it is clear that despite this 'a complex traditional vocabulary... derived from classical, romantic or religious forms flourished' (Winter 1995, 223). This article suggests that, away from intellectual circles, the war was by no means necessarily transformative. Markers of the Italian peasant world shape the language in which the emotions of war and combat were expressed: the family, Catholicism, land and terrain. Through examining the emotional narratives of peasant soldiers we find evidence of considerable continuity of traditional and familiar models of perceiving, interpreting and narrating the subjective experience of war.

\section{Notes}

1. As Peterson and Liaras show, counteracting fear included efforts to inculcate other emotions (2006). 
2. Since the Vietnam war, therapists working with veterans suffering from Post-Traumatic Stress Disorder (PTSD) have used a technique called 'exposure therapy' in which sufferers narrate and relive traumatic experiences in order to lessen their emotional impact.

3. All translations are by the author unless otherwise specified.

4. Since women were less likely to be literate than men (Bravo 1980), adjusted figures for male literacy would be slightly higher. By contrast, by 1905 literacy in France was above $95 \%$.

5. Letters survive in the archives of military tribunals or censors, others in the widely dispersed local collections created on the initiative of Prime Minister Paolo Boselli from 1915, under the auspices of the National Committee for the History of the Risorgimento. Many have been transcribed and published, an invaluable resource enabling scholars to use a much wider range of sources than would be practical relying solely on material from a single archive. This paper draws on published letters from both 'patriotic' and 'anti-patriotic' collections. Caffarena offers a practical research guide to letter collections (2005).

6. Translations of soldiers' letters maintain, so far as possible, the original idiosyncrasies of grammar, punctuation and capitalisation. Inexpert writers sometimes used initial capitals to provide emphasis, while grammar errors were sometimes revealing of linked thought processes.

7. See trench journal La Tradotta issue 4, April 14, 1918, for one example. On the use of religious imagery, especially from the Old Testament, in war poetry see Winter (1995).

8. Meyer discusses similar emotional and linguistic loss of control among British troops (2003).

\section{References}

Bellassai, S. 2005. The masculine mystique: Antimodernism and virility in fascist Italy. Journal of Modern Italian Studies 10, no. 3: 314-35.

Bellosi, G., and Marcello S., eds. 2002. Verificato per censura. Lettere e cartoline di soldati romagnoli nella prima guerra mondiale. Cesena: Società Editrice 'Il Ponte Vecchio'.

Beltrame Menini, L., ed. 2001. Adorata Luigia. Mio diletto Antonio. Storia d'amore e di guerra (1910-1919). Padua: Panda Edizioni.

Bourke, J. 1999. An intimate history of killing: Face-to-face killing in twentieth century warfare. London: Granta.

Bourke, J. 2005. Fear: A cultural history. London: Virago.

Bravo, A. 1980. Donne contadine e prima guerra mondiale. Società e Storia III, no. 10: 843-62.

Cadorna, L. 1967. Lettere famigliari, ed. R. Cadorna, Milan: Mondadori.

Caffarena, F. 2005. Lettere dalla Grande Guerra. Scritture del quotidiano, monumenti della memoria, fonti per la storia. Il caso italiano. Milan: Edizioni Unicopli.

Das, S. 2005. Touch and intimacy in First World War literature. Cambridge: Cambridge University Press.

Edmonds, J. 1949. Military operations in Italy 1915-1919. London: HMSO.

Favetti, G. 2004. L'esercito della morte. Dall'Africa al Carso, il diario di un volontario irredento, ed. Giuseppe. Magrin, Udine: Gaspari.

Forcella, E. and A. Monticone. 1968. Plotone d'esecuzione. I processi della prima guerra mondiale. Rome-Bari: Laterza.

Frescura, A. 1981. Diario di un imboscato. Milan: Mursia.

Fussell, P. 1975. The Great War and modern memory. Oxford: Oxford University Press.

Garrone, G. and E. Garrone. 1974. Lettere e diari di guerra 1915-1918. Milan: Garzanti.

Gatti, A. 1964. Caporetto. Diario di guerra. Bologna: Il Mulino.

Gemelli, A. 1917. Il nostro soldato. Saggi di psicologia militare. Milan: Treves.

Gentile, E. 2008. L' apocalisse della modernità. La Grande guerra per l'uomo nuovo. Milan: Mondadori. 
Gibelli, A. 1987. Pratica della scrittura e mutamento sociale. Orientamento e ipotesi. Materiali di lavoro, no. 1-2: 7-20.

Gibelli, A. 1998a. L'officina della guerra. La Grande Guerra e la trasformazione del mondo mentale. Turin: Bollati Boringhieri.

Gibelli, A. 1998b. La Grande Guerra degli italiani 1915-1918. Florence: Sansoni.

Gibelli, A. 2002. Nefaste Meraviglie. Grande Guerra e apoteosi della modernità. In Storia d'Italia 18. Guerra e Pace, ed. W. Barberis. Turin: Einaudi.

Grossman, D.A. 1995. On killing: The psychological cost of learning to kill in war and society. New York: Back Bay Books.

Isnenghi, M. 1967. I vinti di Caporetto nella letteratura di guerra. Padua: Marsilio Editori.

Isnenghi, M. 2002. Il mito della grande guerra. Bologna: Il Mulino. 1st ed. 1970.

Ius, L. and M. Ius. 2003. Vivere e morire da volontari. I diari di guerra di due fratelli bersaglieri, ed. Fabio. Todero. Udine: Gaspari.

Leed, E. 1979. No man's land: Combat and identity in World War I. Cambridge: Cambridge University Press.

Loez, A. 2003. Tears in the trenches: A history of emotions and the experience of war. In Uncovered fields: Perspectives in First World War studies, ed. J. Macleod and P. Purseigle, 211-26. Leiden: Brill.

Macleod, J. and P. Purseigle, eds. 2003. Uncovered fields: Perspectives in First World War studies. Leiden: Brill.

Marshall, S.L.A. 2000. Men against fire: The problem of battle command. Norman: University of Oklahoma Press.

Meyer, J. 2003. 'Gladder to be going out than afraid': Shellshock and heroic masculinity in Britain, 1914-1919. In Uncovered fields: Perspectives in First World War studies, ed. J. Macleod and P. Purseigle, 195-210. Leiden: Brill.

Ministero della Guerra, Ufficio Statistico. 1927. Statistica dello sforzo militare italiano nella guerra mondiale, ed. G. Mortara. Rome: Provveditorato generale dello stato.

Olson, D. 1994. The world on paper: The conceptual and cognitive implications of writing and reading. Cambridge: Cambridge University Press.

Petersen, R.D. and E. Liaras. 2006. Countering fear in war: The strategic use of emotion. Journal of Military Ethics 5, no. 4: 317-33.

Procacci, G. 2000. Soldati e prigionieri italiani nella Grande guerra. Con una raccolta di lettere inedite. Turin: Bollati Boringhieri.

Revelli, N. 1977. Il mondo dei vinti. Turin: Einaudi.

Rochat, G. 1990. Gli arditi della Grande Guerra: origini, battaglie e miti. Gorizia: Libreria Editrice Goriziana.

Roper, M. 2009. The secret battle: Emotional survival in the Great War. Manchester: Manchester University Press.

Rosenwein, B.H. 2002. Worrying about emotions in history. American Historical Review 107, no. 3: $821-45$.

Scherer, K.R. 2005. What are emotions? And how can they be measured? Social Science Information 44, no. 4: 695-729.

Scott, J.C. 1985. Weapons of the weak: Everyday forms of peasant resistance. New Haven: Yale University Press.

Spitzer, L. 1976. Lettere di prigionieri di guerra italiani (1915-1918), trans. R. Solmi. Turin: Bollati Boringhieri.

Stephens, K. 2000. A critical discussion of the 'New Literacy Studies'. British Journal of Educational Studies 48, no. 1: 10-23.

Watson, A. and P. Porter. 2010. Bereaved and aggrieved: Combat motivation and the ideology of sacrifice in the First World War. Historical Research 83, no. 219: $146-64$. 
Wilcox, V. 2005. Discipline in the Italian army, 1915-1918. In Warfare and belligerence: Perspectives in First World War studies, ed. P. Purseigle, 73-100. Leiden: Brill.

Winter, J. 1995. Sites of memory, sites of mourning: The Great War in European cultural history. Cambridge: Cambridge University Press.

Winter, J. and A. Prost. 2005. The Great War in history: Debates and controversies, 1914 to the present. Cambridge: Cambridge University Press. 